\title{
Language and Knowledge Tests for Permanent Residence Rights: Help or Hindrance for Integration?
}

\author{
Anita Böcker and Tineke Strik* \\ Centre for Migration Law, Radboud University Nijmegen, Nijmegen, The Netherlands
}

\begin{abstract}
More and more Member States require immigrants from outside the EU to pass language or knowledgeof-society tests in different stages of the immigration and integration process. This article focuses on the application of this requirement as a condition for obtaining a permanent residence permit or the EU long-term resident status. It is based on an international comparative study that included seven Member States with integration conditions (Austria, Denmark, France, Germany, Latvia, the Netherlands and the United Kingdom). The article analyses the reasons behind the introduction of language and knowledge tests for applicants for a permanent residence permit or the EU long-term resident status in these Member States. Secondly, it examines the effects of the tests on the integration process of third-country nationals admitted for non-temporary stay. Finally, it discusses the legal constraints posed by EU and international law.
\end{abstract}

\section{Keywords}

integration, language test, permanent residence, long-term residents, Directive 2003/109, Directive 2003/86, Decision 1/80, EEC/Turkey Association Agreement

\section{Introduction}

Many EU Member States have defined integration requirements that must be met by non-EU immigrants seeking permanent residence. These requirements increasingly take the form of having to pass a formal language or knowledge-ofsociety test. Currently, there are eleven Member States that have made access to permanent residence conditional on the passing of an examination. ${ }^{1}$ With the exception of Denmark and the United Kingdom (where the Long-Term Residents Directive does not apply), they have also made this a condition for the acquisition of the EU long-term resident status. Thus, immigrants who fail or refuse to take the examinations may be excluded from gaining a secure residence status and the rights attached to it.

The introduction of these requirements signifies a reversal of the idea that a secure status facilitates the integration process. That idea was a premise of many

\footnotetext{
1) Austria, the Czech Republic, Denmark, Estonia, France, Germany, Greece, Latvia, Malta, the Netherlands and the United Kingdom.
} 
national integration policies during the 1980s and most of the 1990s. The same idea was also behind the European Commission's proposals for the first two Directives on the status of third-country nationals following the widening of the EU competences in the field of immigration which came into force in 1999: the Family Reunification Directive (2003/86/EC) and the Directive on the Status of Long-Term Resident Nationals of Third Countries (2003/109/EC). However, at the time of the negotiations about both Directives, support for this premise had already eroded in some Member States. Therefore, Article 5(2) of the Long-Term Residents Directive allows Member States to require third-country nationals 'to comply with integration conditions, in accordance with national law' when applying for long-term resident status. Similarly, Article 7(2) of the Family Reunification Directive allows Member States to require third-country nationals to comply with integration measures. This article is applicable to both admission and the granting of an autonomous residence permit.

The new integration requirements imply that immigrants have to 'earn' their right to permanent residence (and the rights attached to it) by demonstrating their willingness and ability to integrate. A similar reversal in thinking about the relation between a strong legal position and integration had already manifested itself with regard to naturalisation. In the early 2000s, many Member States introduced formal language and knowledge-of-society tests for applicants for naturalisation. More recently, a tendency has become apparent to also introduce examinations at an earlier stage of the immigration process. Several Member States require applicants for family reunification to pass a 'pre-entry' test. $^{2}$

This article will address the following questions:

- What types of language and knowledge requirements are currently applied to immigrants seeking permanent residence in different Member States?

- What is the rationale behind the introduction of these requirements for immigrants seeking permanent residence? How do they relate to language and knowledge requirements in other stages of the immigration and nationality law system?

- What are the effects of the requirements? To what extent are the stated aims being achieved? Are there unintended effects?

- What are the legal constraints?

To answer these questions, we draw on the results of the INTEC study: a comparative study in nine Member States on the application and effects of language or knowledge tests in different stage of the immigration and nationality law system. ${ }^{3}$ Seven of the participating Member States (Austria, Denmark, France,

\footnotetext{
2) See Groenendijk, C. (2011). Pre-departure integration strategies in the European Union: Integration or immigration policy? European Journal of Migration and Law 13(1), pp. 1-30.

3) Strik, A., et al. (2010). Integration and Naturalisation Tests: The New Way to European Citizenship. Syn-
} 
Germany, Latvia, the Netherlands and the United Kingdom) require immigrants seeking permanent residence to pass an examination; the other two (Belgium and Hungary) do not apply such a requirement.

The research team consisted of experts from each of the participating countries. These national experts analysed the political debates and decision-making processes on integration requirements. They also described the content and the target group of the requirements. Furthermore, they tried to assess the impact of the requirements. Besides existing evaluation studies, case law and statistical data, the most important source of information for this part of the research were interviews.

Most of the interviews about integration requirements for immigrants seeking permanent residence were with immigrants who had been or were required to fulfil these requirements: a total of 127 immigrants were interviewed in Austria, Belgium, Denmark, Germany, the Netherlands and the United Kingdom. In addition, interviews were conducted with teachers and language school representatives (29 interviews), public officials (27), and staff or active members of immigrant organisations and other NGOs (31). The interviews with immigrants were arranged through different channels, and the researchers strived for diversity among the respondents in terms of gender, nationality, age and educational level. However, as it was not possible to use interpreters, the research teams in most countries could only conduct interviews with immigrants who were sufficiently proficient in the language of the country of immigration or, e.g., English.

The analysis in the following sections will be restricted to the countries covered by the INTEC study.

\section{The Requirements}

\subsection{Nature, Content and Level}

Immigrants seeking permanent residence in Austria, Denmark, France, Germany, Latvia, the Netherlands or the United Kingdom are required to prove that they have sufficient knowledge of the language (and society) of the country. By making compliance with language or knowledge-of-society requirements a precondition for a secure legal status, these Member States have shifted the responsibility for integration more toward the immigrant. However, there are important differences in how the responsibility, also financially, is divided, and in the content and level of the required knowledge.

thesis report. Centre for Migration Law, Nijmegen. The INTEC Project was financed by the European Integration Fund. The synthesis report and the nine country reports are available online on the website of the Centre for Migration Law, www.ru.nl/rechten/cmr. 
Immigrants admitted for non-temporary purposes in Germany, Austria, Denmark, France and the Netherlands are, or may be, required to attend official integration programmes. In the latter four countries, they are required to sign an 'integration contract', which they have to fulfil within a certain period of time, and in which the content of the integration programme is specified. The German federal government also intends to introduce integration contracts. In all five countries, immigrants who have successfully completed their integration programme are eligible for a permanent residence permit or the EU long-term resident status, provided that they fulfil the other requirements.

The United Kingdom and Latvia have chosen a less paternalistic (and less educational) approach. Immigrants admitted for non-temporary purposes are not required to attend a programme or sign a contract. It is only when they apply for a permanent or (in Latvia) long-term residence status that they have to demonstrate sufficient knowledge of the language and (in the United Kingdom) society by passing an examination. They have to prepare themselves for the examination. In the United Kingdom, however, immigrants who do not have sufficient language skills are offered an alternative route. They can attend English language and citizenship classes at an accredited institute and demonstrate that they have made at least one level progress.

Belgium and Hungary do not require immigrants seeking permanent residence to prove that they have sufficient knowledge of the language (and society) of the country. However, the Flemish Region of Belgium does require immigrants living permanently in Flanders to attend an integration programme. Immigrants who belong to the target group are required to sign and fulfil an 'integration contract' in which the content of the programme is specified.

Table 1 gives an overview of the requirements currently applied in the countries studied. In the seven Member States where immigrants seeking permanent residence have to pass an examination, the content and level of the examination differ. It always includes a language test or, if it does not, a certain level of language proficiency is needed to pass the knowledge-of-society test. The language requirements can be compared by using the proficiency levels of the Council of Europe's Common European Framework of Reference for Languages (CEFR). There are three broad levels, A, B and C, with two sub-levels in each, A1 being the lowest (beginners level) and $\mathrm{C} 2$ the highest (proficient user). The required level ranges from A.1.1 (which is somewhat below A.1) in France to B1 in Denmark, Germany and the United Kingdom. In several countries, the level has been raised shortly after the introduction of the requirement.

There are large differences in costs for the immigrants, also among the five countries with compulsory contracts and/or programmes. Whereas the courses in Denmark and France are free of charge for the immigrants who are obliged to attend them, immigrants in the Netherlands, Germany and Austria have to pay part of the costs themselves. In the latter two countries, those who pass the 
Table 1. Language and Knowledge-of-society Requirements for Immigrants Seeking Permanent Residence (2010)

\begin{tabular}{|c|c|c|c|}
\hline & Type of requirement & Content and level & $\begin{array}{l}\text { Sanctions for } \\
\text { non-compliance* } \\
1 \quad \begin{array}{l}\text { no permanent } \\
\text { residence permit }\end{array} \\
2 \begin{array}{l}\text { no renewal of } \\
\text { temporary permit }\end{array} \\
3 \text { administrative fine } \\
4 \quad \begin{array}{l}\text { withdrawal or } \\
\text { cutting of social } \\
\text { benefits }\end{array}\end{array}$ \\
\hline Austria & $\begin{array}{l}\text { - integration contract and } \\
\text { German and integration } \\
\text { course for (certain } \\
\text { categories of) newcomers; } \\
\text { - requirement to prove } \\
\text { language skills by success- } \\
\text { fully completing German } \\
\text { and integration course or } \\
\text { providing officially recog- } \\
\text { nised language certificate } \\
\text { within } 5 \text { years after arrival }\end{array}$ & language (A2) & $1,(2), 3$ \\
\hline $\begin{array}{l}\text { Flemish } \\
\text { Region } \\
\text { (Belgium) }\end{array}$ & $\begin{array}{l}\text { - integration contract and } \\
\text { programme for newcomers } \\
\text { and certain other } \\
\text { categories of immigrants; } \\
\text { - no requirement to pass an } \\
\text { examination }\end{array}$ & $\begin{array}{l}\text { language (A1) } \\
\text { and introduction } \\
\text { to Flemish and } \\
\text { Belgian society }\end{array}$ & 3,4 \\
\hline Denmark & $\begin{array}{l}\text { - integration contract and } \\
\text { programme for newcomers; } \\
\text { - requirement to pass } \\
\text { examination; } \\
\text { - 'active citizenship' } \\
\text { requirement }\end{array}$ & $\begin{array}{l}\text { language (B1); } \\
\text { knowledge of } \\
\text { Danish society, } \\
\text { culture and history } \\
\text { will be tested in } \\
\text { 'active citizenship } \\
\text { test' (to be } \\
\text { implemented in } \\
\text { 2011) }\end{array}$ & 1,4 \\
\hline France & $\begin{array}{l}\text { - integration contract and| } \\
\text { programme for newcomers; } \\
\text { - newcomers with } \\
\text { insufficient language skills } \\
\text { are required to complete a } \\
\text { language course during } \\
\text { first year of residence }\end{array}$ & $\begin{array}{l}\text { language (A1.1) } \\
\text { and knowledge of } \\
\text { society }\end{array}$ & $(1),(2)$ \\
\hline
\end{tabular}


Table 1 (cont.)

\begin{tabular}{|c|c|c|c|}
\hline & Type of requirement & Content and level & 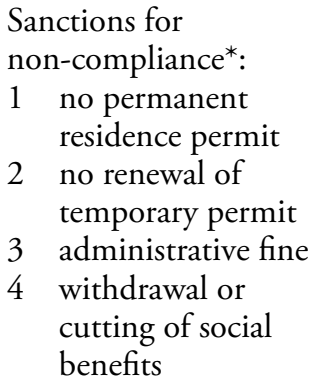 \\
\hline Germany & $\begin{array}{l}\text { - integration programme } \\
\text { for newcomers and } \\
\text { certain other categories } \\
\text { of immigrants; } \\
\text { - programme is completed } \\
\text { by examination }\end{array}$ & $\begin{array}{l}\text { language (B1) } \\
\text { and knowledge of } \\
\text { Germany's legal } \\
\text { system, culture and } \\
\text { history }\end{array}$ & $(1),(2), 3,4$ \\
\hline $\begin{array}{l}\text { Hungary } \\
\text { Latvia }\end{array}$ & $\begin{array}{l}\text { n.a. } \\
\text { - requirement to pass a } \\
\text { language test for applicants } \\
\text { for a permanent residence } \\
\text { permit or the EU long- } \\
\text { term resident status }\end{array}$ & $\begin{array}{l}\text { n.a. } \\
\text { language (A2) }\end{array}$ & $\begin{array}{l}\text { n.a. } \\
1\end{array}$ \\
\hline Netherlands & $\begin{array}{l}\text { - integration contract and } \\
\text { programme for newcomers } \\
\text { and certain other } \\
\text { categories of immigrants; } \\
\text { - requirement to pass } \\
\text { 'integration examination' } \\
\text { within } 3.5 \text { years after } \\
\text { arrival }\end{array}$ & $\begin{array}{l}\text { language (A2) and } \\
\text { knowledge of } \\
\text { Dutch society }\end{array}$ & $1,3,4$ \\
\hline $\begin{array}{l}\text { United } \\
\text { Kingdom }\end{array}$ & $\begin{array}{l}\text { - requirement to pass 'Life } \\
\text { in the UK test' for } \\
\text { applicants for indefinite } \\
\text { leave; immigrants with } \\
\text { insufficient language skills } \\
\text { may opt for attending a } \\
\text { course }\end{array}$ & $\begin{array}{l}\text { language (B1) and } \\
\text { knowledge of life } \\
\text { in the UK; } \\
\text { for those who have } \\
\text { opted for course: } \\
\text { progress of at least } \\
\text { one level }\end{array}$ & 1 \\
\hline
\end{tabular}

* (1) or (2) between brackets means that the consequences of non-compliance are not straightforward.

examination within a given time period can claim part of their contributions back. In the Netherlands, the government sought to privatise the courses. The idea was to make the immigrants themselves responsible (also financially) for acquiring the required knowledge and skills; the government would only define 
the requirements. However, it soon became clear that this did not work (empty classrooms), and the municipalities were again made responsible. The centreright government that came into power in October 2010 intends to change the system again.

\subsection{Sanctions}

The consequences for immigrants who fail to comply differ from country to country and may range from not being eligible for permanent residence status to being threatened with expulsion. Failure to comply may also lead to financial penalties (see Table 1).

In five countries (Austria, Denmark, Latvia, the Netherlands, the United Kingdom), immigrants who are not able to prove that they have sufficient knowledge of the language (and society) of the country are not eligible for a permanent residence permit or the EU long-term resident status and the rights attached to it. They will have to apply for renewal of their temporary residence permit. In Latvia and the United Kingdom, there are no other penalties. Denmark and the Netherlands also have financial penalties for immigrants who fail to comply with the obligation to complete a language and integration programme.

In Germany and France, too, immigrants seeking permanent residence are in principle required to prove sufficient language knowledge, but the consequences for those who fail to do so are less straightforward than in the other five countries. In Germany, it will depend on whether the immigrant in question has attended the language and integration course 'properly'. In France, the issuance of a permanent permit is conditional on the immigrant's 'republican integration', which leaves wide margins of discretion to the immigration authorities. It is not clear how much weight they attach to the applicant's having passed the examination at the end of the language course.

On the other hand, both in Germany and France as well as in Austria, an immigrant's failure to comply with integration requirements may also have consequences for the renewal of his/her temporary residence permits. In Germany, renewal applications may be refused because of 'gross and repeated failure' to comply with the obligation to attend a course. However, as the immigrant's duration of stay in Germany, his/her ties with Germany, and the consequences for his/ her family members must be taken into account, this penalty will rarely be imposed. In France, there appear to have been no cases where immigrants were refused a renewal of their temporary permit on this ground. In Austria, three deportation orders had been issued until 2009; in all three cases, the appeal was still pending at the time of our research. The centre-right government that came into power in the Netherlands in October 2010 has announced that it will make it possible to withdraw the temporary residence permits of immigrants who do not pass the Dutch language and knowledge-of-society examination. 


\subsection{Target Groups}

The target group has been defined differently by each of the seven countries that require applicants for a permanent residence permit or the EU long-term resident status to pass a test or to complete a course. However, it always includes newly arrived immigrants who have been admitted for family reunification, and in most countries, a large majority of the target group falls into this category. Immigrants who have been granted asylum do not always belong to the target group; they are not required to comply with the language or knowledge-of-society requirements in Austria, Latvia and the United Kingdom. Many labour migrants in all seven countries will not have to fulfil these requirements because their stay is (assumed to be) of a temporary nature. The Austrian legislation contains an explicit exception for highly skilled labour migrants: non-EU/EEA immigrants who intend to stay in Austria for more than 24 months have to sign an integration contract, but 'key personnel' and their family members are regarded as already having fulfilled the integration contract. France has a similar exception for holders of a 'skills and talents' visa; they are not required to fulfil the integration contract. The Dutch legislation contains an exception in the opposite direction: ministers of religion are the only category of (assumedly) temporary migrants who are required to complete an integration course in the Netherlands.

EU/EEA citizens and their family members are always excluded from the target group. The family members of own nationals, on the other hand, are always included. In the United Kingdom, however, the parent, grandparent or other dependent relative of a British citizen or settled person are exempt from the 'Life in the UK' test. In the United Kingdom, Turkish businesspersons recognised under the Association Agreement with Turkey are also exempt from the 'Life in the UK' test. There is no similar exception for Turkish workers. The other countries do not have any exceptions for Turkish citizens. However, in Germany the sanctions for non-compliance with the obligation to attend an integration course are not applied to Turkish workers and their family members. In Denmark, foreigners 'with strong ties to Denmark' are exempted from the new 'active citizenship' requirement; this exemption applies to foreigners belonging to the Danish minority in South Schleswig, former Danish citizens, foreigners with Danish parents, and Argentinean citizens with Danish parents or grandparents.

Most countries have age limits. Several countries have limited the target group to persons aged between 18 and 65; other countries have exemptions for older persons or pensioners and/or for younger persons. Most countries with examinations have two (other) types of exemptions: one for migrants who are assumed to have attained a sufficient level of knowledge or integration, and the other for migrants who are incapable of taking the examinations. In most countries, immigrants who can prove their integration or knowledge of the language with particular diplomas or certificates are not required to take the examination. The same applies to young immigrants who are still in education. In addition, most coun- 
tries have exemptions for disabilities or long-term illnesses that severely restrict the ability to speak or learn the language or to prepare for the integration test. The formulation of this exemption in the Danish legislation (handicapped persons may be exempted from fulfilling requirements, which they are not able to fulfil, provided that it is required by Denmark's international obligations) has aroused much criticism, because it leaves wide margins of discretion to the immigration authorities. Various respondents in Denmark pointed out that it is very difficult to grant or be granted exemption, because it is only allowed in cases where psychological or physical disabilities prevent the applicant from ever fulfilling the requirements (it is not allowed in cases where the applicant's health or mental situation may improve). Various respondents in Austria, the Netherlands and the United Kingdom also pointed out difficulties with getting exemptions for disabled or, e.g., traumatised persons. Respondents in the United Kingdom pointed out the absence of a specific procedure for exemption on grounds of incapacity before an application was made. Respondents in the Netherlands thought that traumatised refugees sometimes had difficulty obtaining the required medical certificate. Respondents in Austria thought that the threshold for exemption on grounds of incapacity was too high.

In Germany, immigrants who have to look after a handicapped family member can also apply for an exemption. The United Kingdom also has exemptions for, e.g., victims of domestic violence and foreign nationals discharged from the armed forces.

Finally, it is noteworthy that in Germany, the Netherlands and the Flemish Region in Belgium, not only newly arrived immigrants but also immigrants who have lived in the country for a long time (and who may already have a permanent residence permit) can be obliged to attend a course if their language skills are considered to be insufficient. In Germany, this applies to foreigners who receive unemployment benefits and to foreigners who have 'special integration needs'. The latter category includes parents of minor children living in Germany who are dependent on social assistance. In the Netherlands, it applies to foreigners who do not have a diploma proving that they have sufficient knowledge of the Dutch language. In Flanders, it applies to foreigners as well as foreign-born Belgians who receive social assistance. In all three countries, failure to comply may be punished by an administrative fine or by the reduction or withdrawal of social benefits.

\section{Rationale and Dynamics}

\subsection{Stated and Latent Aims}

In each of the Member States where immigrants are required to pass a test or to attend a course, the stated aim is to facilitate their integration. The background 
to the introduction of the requirements was, in nearly all cases, an apparent or perceived crisis of integration. ${ }^{4}$

Latvia is an exception in that the debate in this country has not concentrated on the need to promote the integration of immigrants. Their numbers are insignificant in Latvia. The Latvian debate has concentrated on 'non-citizens', i.e., former Soviet citizens who migrated to or were born in Latvia during Soviet occupation and who after 1991 did not qualify for Latvian citizenship. The debate focused mainly on whether these non-citizens should be entitled to EU citizenship and what requirements they would have to meet to acquire the long-term resident status. Otherwise, there has not been much debate about the language requirement for applicants for a permanent residence permit or the EU long-term resident status. There was a broad consensus that knowledge of the Latvian language should be required.

Two main concerns are discernible in the debates in most other countries. The first is to make permanent immigrants economically self-supporting, to lower their unemployment rates and to reduce the costs they incur to the state in the form of welfare expenses. In the Netherlands, the multicultural minorities' policy that had been introduced in the 1980s was increasingly criticised for 'pampering' ethnic minorities and failing to reduce their unemployment rates in the 1990s. In the debate about the introduction of compulsory integration courses, it was emphasised that newcomers should acquire the necessary skills to find employment and become economically self-sufficient as quickly as possible. ${ }^{5}$ In Germany, the aim of the integration courses was formulated as to enable foreigners to cope with all areas of daily life without the help or intervention of third parties'. ${ }^{6}$ In the United Kingdom, the extension of the requirement to pass the 'Life in the UK' test to applications for indefinite leave was justified as follows: 'permanent migrants must be as economically active as possible; put as little burden on the state as possible; and be as socially integrated as possible." ${ }^{7}$

The second concern, which became more important with the post-2001 wave of terrorist activities and unrest associated with Muslim communities in various Member States, is to familiarise immigrants with the history and culture of the country of immigration and to inculcate in them the values and principles of liberal democracy. In the United Kingdom, where cultural pluralism had been accepted by policy-makers since the late 1960s, the catalyst for change was a series of riots involving young Muslim men of Pakistani and Bangladeshi origin in 2001. In a report entitled 'Building Cohesive Communities', the government

4) Cf. Michalowski, I. (2007), Integration als Staatsprogramm: Deutschland, Frankreich und die Niederlande im Vergleich. LIT Verlag, Münster.

5) See, e.g., Van Oers, R., De Hart, B. and Groenendijk, K. (2010), The Netherlands. EUDO Citizenship Observatory. European University Institute, Badia Fiesolana.

6) Aufenthaltsgesetz, section 43(2).

7) Home Office (2005), Controlling our Borders: Making Migration Work for Britain. TSO, p. 21. 
concluded that there was a need to promote 'a uniting identity' and 'shared values' to give people 'a common sense of belonging. ${ }^{8}$

Particularly in Germany, where the 'right to participate' was stressed, an additional argument for obliging immigrants to attend courses was that women who were isolated at home could be accessed and brought into German society using this instrument.

However, there are other, more latent aims and concerns as well, such as the desire to limit access to permanent residence to 'well integrated' immigrants or to assure the native population that the government or the mainstream political parties are managing the crisis efficiently. ${ }^{9}$ The clearest examples are Denmark, Austria and the Netherlands, where electoral shifts towards populist anti-immigrant parties have put the mainstream parties under pressure to adopt other discourses and positions. The desire to limit access to permanent residence to 'well integrated' immigrants is a rather manifest aim of the tests in all three countries. For example, in Denmark, in the legislative debate about the latest sharpening of the integration requirements, it was explicitly stated that one of the aims was to make it more difficult for immigrants who are 'not well integrated' to obtain permanent residence. In Austria, the Freedom Party (FPÖ) presented the introduction of the integration contract as a major political success and as a paradigm shift towards a more restrictive immigration policy. The head of the parliamentary FPÖ party described the contract as a device for selection and as a remedy for 'immigration into the welfare system'. ${ }^{10}$

\subsection{Strengthening and Spreading}

In the Member States with integration contracts and programmes, there has been a tendency toward a more compelling approach. The Netherlands and France first introduced voluntary contracts. A few years later, they made them compulsory. In Germany, although there was reluctance to emphasise the compulsory aspect of the courses, this aspect has become increasingly important. In March 2011, the German legislator reinforced the obligation for immigration authorities to assess the degree of compliance with integration requirements, before they decide on renewal of the temporary residence permit. If the applicant has not attended the integration course properly, they may only extend the permit for one year. Currently, the federal government plans to introduce integration contracts based on the French model. These should help to make integration efforts 'more binding'.

\footnotetext{
8) Home Office (2001), Building Cohesive Communities: A Report of the Ministerial Group on Public Order and Community Cohesion. TSO, pp. 19-20.

9) Joppke, C. (2007), Do obligatory civic integration courses for immigrants in Western Europe further integration? Focus Migration Policy Brief 8.

10) Österreichisches Parlament 09.07.2002, 52, cited in Mourão-Permoser, J. (2010), Redefining Membership. European Union Policy on the Rights of Third Country Nationals, Ph.D. Thesis, University of Vienna, p. 198.
} 
Most significantly, in all five countries with integration contracts or programmes, their fulfilment or successful completion has been made a precondition for permanent residence sooner or later after their introduction.

There also has been a tendency to raise the required level of language proficiency. In Denmark, immigrants seeking permanent residence have been required to pass a language examination since 2002. However, until 2007, they simply had to pass an examination at the level of the course in which they had been enrolled. In 2007, the required level was set at B1 for all applicants. In France, there are plans to raise the required level from A.1.1 to A1 or A2. In Austria an amendment was adopted in February 2011 to the effect that immigrants admitted for non-temporary stay will be required to attain level A2 in two years (with deportation as sanction for non-compliance), and then level B1 in five years (with noneligibility for the EU long-term resident status as sanction).

Another tendency becomes visible when the integration conditions applied in different stages of the immigration and nationality law system are compared (see Table 2). Among the seven countries that require immigrants seeking permanent residence to pass a language (and knowledge-of-society) test, there are six that also use a standardised test in the naturalisation procedure. ${ }^{11}$ France is the only exception. It does require applicants for naturalisation to demonstrate sufficient knowledge of the French language and the rights and duties conferred by French citizenship, but has this tested in an interview with a civil servant. Moreover, all but one of these countries have also introduced 'pre-entry' tests. The Netherlands, Germany, Denmark, the United Kingdom and Austria have made passing a language and knowledge-of-society test a condition for a visa for family reunification for certain third-country nationals. France also uses a pre-entry test, but passing it is not a condition for family reunification; those whose language proficiency is found to be insufficient are only required to attend a language course.

Apparently, once a test has been introduced in one stage, other tests tend to follow. Most of the countries studied were already applying language (and knowledge-of-society) requirements in the naturalisation procedure in the 1990s. However, the applicant's knowledge was tested in an interview with a civil servant (the Netherlands, Denmark, France and some of the German federal states), or it was assumed to be sufficient (United Kingdom). Latvia and Hungary introduced standardised naturalisation tests already in the 1990s, when they adopted new citizenship laws. Denmark, the Netherlands and the United Kingdom introduced standardised naturalisation tests in the early 2000s, when they abandoned the idea of naturalisation as a means of integration. Sooner or later, this also influenced the requirements for permanent residence. A few other Member States (Austria, Germany) first made the successful completion of an integration programme a precondition for permanent residence. Once this requirement had 11) In the Netherlands and the United Kingdom, the same examination is used for permanent residence
and naturalisation. 
Table 2. Introduction of Standardised Language and Knowledge Tests in Different Stages of the Immigration and Nationality Law System*

\begin{tabular}{llll}
\hline & Naturalisation & Permanent residence & Admission \\
\hline Denmark & $2002 \mathrm{~B} 1$ & 2002 (no fixed level) & \\
& $2006 \mathrm{~B} 2$ & $2007 \mathrm{~B} 1$ & $2010 \mathrm{~A} 1-$ \\
& $2007+\mathrm{KoS}$ & $2011+\mathrm{KoS}$ & \\
\hline Netherlands & $2003 \mathrm{~A} 2+\mathrm{KoS}$ & $\begin{array}{l}2007 \mathrm{~A} 2+\mathrm{KoS} \\
2010 \mathrm{~A} 2+\mathrm{KoS}\end{array}$ & $\begin{array}{l}\text { 2006 A1- } \\
\text { 2011 A1 (to be implemented) }\end{array}$ \\
\hline Austria & $2006 \mathrm{~A} 2+\mathrm{KoS}$ & $2003 \mathrm{~A} 2$ & $2011 \mathrm{~A} 1$ (to be implemented) \\
\hline Germany & $2007 \mathrm{~A} 2$ & $(2005 \mathrm{~B} 1)$ & $2007 \mathrm{~A} 1$ \\
\hline UK & $2008+\mathrm{KoS}$ & $2010 \mathrm{~A} 1$ \\
\hline France & $2004 \mathrm{~B} 1$ & $2007 \mathrm{~B} 1+\mathrm{KoS}$ & $2007 \mathrm{~A} 1.1)$ \\
\hline Latvia & $1995 \mathrm{~B} 1+\mathrm{KoS}$ & $2003 \mathrm{~A} 2$ & \\
\hline Hungary & 1993 & & \\
\hline
\end{tabular}

* Year of entry into force as a requirement for the granting of citizenship, permanent residence or the EU long-term resident status, or entry visas. (Year) between brackets means that passing the test is not a straightforward requirement. KoS = Knowledge of Society.

been adopted, it was decided to also introduce a standardised test in the naturalisation procedure, because politicians did not want to require less from immigrants who applied for the stronger legal position.

Moreover, in several Member States, the introduction of language and knowledge tests for permanent residence appears to have had an upward effect on the level of the naturalisation test. For example, in Denmark, when the level for permanent residence was set at $\mathrm{B} 1$, it was decided to raise the level for naturalisation from B1 to B2. In Austria the level for both tests was set at A2, and in Germany it was set at B1, but both countries made the test for naturalisation more demanding by adding a knowledge-of-society examination. In the Netherlands, the decision to use the same test in both procedures soon led to calls for raising the level for naturalisation.

Finally, more and more Member States have introduced pre-entry tests. In the Netherlands, the decision to introduce these pre-entry tests was taken simultaneously with the decision to make permanent residence conditional upon passing a language and knowledge test. Since 2006, five Member States have followed the Dutch example.

The rapid adoption of integration tests by Member States that were known for their distinct national integration paradigms can be seen as attesting to a 
convergent trend in integration policies. ${ }^{12}$ Generally, there are three explanations for the convergence of national policies: international regimes and institutions, learning processes in which countries learn from experiences in other countries, and parallel but autonomous domestic forces. In this case, all three explanations appear to be relevant.

Directives 2003/86/EC and 2003/109/EC both allow Member States to apply integration requirements. Austria, Germany and the Netherlands were the strongest advocates for this option. The negotiations on the Directives as well as the exchange on the implementation in the contact committees of civil servants, have inspired other Member States to use these options themselves. Even France, which initially opposed the insertion of the clauses, has applied them. ${ }^{13}$ The Dutch conservative-liberal Minister Verdonk, advocating integration requirements for admission and permanent residence rights, promoted the Dutch integration policies within the EU. During its presidency, the Netherlands organised the first European Ministerial Conference on integration. This resulted in the Justice and Home Affairs Council adopting basic common principles on integration on 19 November 2004. ${ }^{14}$ According to Carrera, these principles provided a first decisive move toward the progressive establishment of an EU Framework on Integration. This Framework resulted inter alia in Handbooks with best practices and the Integration Fund, which promotes and supports Member States to exchange and develop integration policies and programmes. ${ }^{15}$ Furthermore, the Dutch presidency successfully inserted a paragraph on integration of third country nationals in the The Hague Programme. ${ }^{16}$ Compared to the Tampere Programme of 1999, the attention for the issue of integration in the Justice and Home Affairs working programme was innovative.

When the debates in different Member States are compared, it becomes clear that there has also been a readiness to emulate policy measures developed by other Member States. For example, the Süssmuth Commission, referring to positive experiences with integration programmes in the Netherlands and Sweden, proposed to introduce similar courses in Germany. Austrian politicians also referred

\footnotetext{
12) Joppke, C. (2007). Beyond national models: Civic integration policies for immigrants in Western Europe, Western European Politics, 30(1), pp. 1-22.

13) For the negotiation position of France, see Carrera, S. (2009), In Search of the Perfect Citizen? The Intersection between Integration, Immigration and Nationality in the EU, Martinus Nijhoff Publishers, Leiden, pp. 170 and 181.

14) Council of the European Union, Justice and Home Affairs, Council Meeting 2618th, 'Common Basic Principles on Immigrants Integration' 14615/04, 19 November 2004, Brussels. In one of the principles the Council stressed the importance of integration programmes, considering basic knowledge of the host society's language, history and institutions as indispensable for integration.

15) Carrera 2009, supra fn. 13, p. 75.

16) European Council, Presidency Conclusions, 4 and 5 November 2004, 14292/1/04, Brussels, 8 December 2004, Annex I, 'The Hague Programme: Strengthening Freedom, Security and Justice in the European Union', point 1.5, OJ C53/1, 3 March 2005. The European Council characterised integration as a continuous two-way process, requiring basic skills for participation in society.
} 
to positive experiences with integration contracts in the Netherlands when they proposed to oblige newcomers in Austria to sign an Integrationsvereinbarung.

Last but not least, the introduction of integration programmes, contracts and tests has been a response to domestic considerations. In nearly all cases, there was concern and debate about the 'failed integration' of a substantial proportion of the immigrant population.

\section{Effects}

\subsection{Numbers of Immigrants Targeted, Attendance Rates and Pass Rates}

The proportion of immigrants who have to fulfil integration requirements varies widely. In France, nearly 80 per cent of the immigrants who sign a welcoming contract have sufficient French language skills to be exempted from the obligation to complete a language course. In other countries, a much larger proportion of the newcomers are affected by the requirements, either because a large majority are not proficient in the language of the country (Austria, Denmark, Germany, the Netherlands, the Flemish Region in Belgium), or because there are no exemption possibilities for those who are already proficient in the language of the test (United Kingdom).

The attendance rates for compulsory courses and programmes are quite high, but the pass rates for the tests in use in the different countries vary substantially. For example, in France, 90 per cent of the newcomers who attended a language course in 2008 passed the (level A1.1) test at the end of the course. A similar pass rate was attained by those who enrolled for a language test at level B1 in Denmark in 2008. In both the Netherlands and Latvia, 74 per cent of those who took the (level A2) language examinations required for permanent residence in these countries in the years 2007-2009 were successful. In the United Kingdom, too, 74 per cent of the immigrants who sat the (level B1) 'Life in the UK' test in the period July 2007June 2010 were successful. ${ }^{17}$ In Germany, only 46 per cent of those who attended a language and integration course in the period 2005-2008 attained the required level of language proficiency (B1); it has since increased to over 50 per cent.

Pass rates in themselves do not say much as long as it is not known what proportion of the target group has taken the test. In both Austria and the Netherlands, a wide gap was found between the number of immigrants who were given notice that they would have to pass a language (and knowledge-of-society) examination in the coming years, and those who had fulfilled this requirement after one to three years. Those who had fulfilled it were probably not representative of the entire population, but above average motivated and able.

17) The data were obtained by the UK research team through a freedom of information request to the UK Border Agency. 
Where statistics broken down by nationality are available, the pass rates vary considerably by nationality. What emerges is differentiation between developed and developing countries and by immigration category. In the United Kingdom in the period November 2005-June 2010, nationals of New Zealand, Australia, the USA, Canada, and Ireland had a combined pass rate of 98 per cent. For nationals of majority English-speaking states in the Caribbean area, the pass rate was only 70 per cent. There was also significant variation among the non-Englishspeaking states. Whereas the pass rates for Singapore and Japan stood at 95 per cent, various other Asian nationalities had pass rates below 50 per cent. Many of the nationalities with relatively low pass rates had had substantial numbers of persons granted humanitarian status in Britain over the past decade or more. In the Netherlands, the differences are smaller (perhaps because more candidates have attended a course), but they show the same pattern. The Dutch statistics also show differences by sex and by age group. Three years after the introduction of the language and knowledge-of-society test, the pass rate stood at 76 per cent for women, and 83 per cent for men. The pass rate was 85 per cent for candidates younger than 36, as against 60 per cent for candidates older than 55 .

Comparable data are not available for the other countries studied. However, in Denmark, where language courses are offered at different levels, immigrants from non-western countries are proportionally overrepresented in the lowest-level courses, and many of them may never be able to pass the level B1 examination (the level required for a permanent residence permit). In Germany, the first results of a longitudinal study show that a younger age, a higher educational level, and not having been born in Turkey, Russia or another former Soviet Republic or South or East Asia have a positive effect on the progress achieved during the course. $^{18}$

In the United Kingdom, the results from the interviews with immigrants and NGOs confirmed some of the impressions given by the statistics. The 'Life in the UK' test is difficult for those who are not proficient in English, particularly if they have had little formal education. Similar observations were made by respondents in other countries. Nearly all the teachers interviewed in Denmark and Germany and some of the teachers in Austria thought that the required level of language proficiency (B1 in Denmark and Germany, A2 in Austria) was too high for immigrants with little formal education. The German teachers thought that these students could attain level A2 if they did their best, but not level B1. According to the Danish language school respondents, there is a group of immigrants who are stuck in the language school system because they will never be able to pass the B1 level examination. Besides people with little formal education, this group consists of people who do not have a talent for languages and people whose first language 18) Rother, N. (2009), Das Integrationspanel. Entwicklung von alltagsrelevanten Sprachfertigkeiten und
Sprachkompetenzen der Integrationskursteilnehmer während des Kurses, BAMF, Nürnberg. 
belongs to another language family than the Indo-European. Teachers and local officials in the Netherlands also thought that elderly people, illiterates and others with little formal education and traumatised refugees face difficulties fulfilling the integration requirements in their country. The Austrian teachers pointed out that illiterate students cannot attain level A2 within the 75 hours of literacy training and 300 hours of language training provided in Austria.

\subsection{Effects on Integration}

The stated aim of the language and knowledge-of-society requirements is to foster the integration of the target groups. However, in most of the countries studied, the effects on the integration process have not yet been systematically evaluated. Most existing evaluation studies have been restricted to the implementation of the requirements.

The immigrants interviewed for this study had different opinions about the importance of the requirements for their integration. In general, they thought that a language requirement in some form was fair. They felt that knowledge of the language was a precondition for making a life in their country of immigration. In countries which also have knowledge-of-society requirements, these were less well received than the language requirements.

In the countries where immigrants admitted for non-temporary stay are required to attend a language course, the immigrant respondents had quite positive opinions about these courses. Most of them did not seem to mind the compulsory nature of the courses. However, both in the Netherlands and the Flemish Region of Belgium, where not only newcomers but also settled immigrants can be obliged to complete an integration programme, the latter group objected to this obligation. They thought that it came too late for them. For many respondents who had been obliged to sign a contract and/or to attend a course as newcomers, it was difficult to distinguish between this obligation and the requirement to have fulfilled the contract and/or to have successfully completed the course as a precondition for permanent residence. Many of them stressed that they would have learnt the language also if it had not been a requirement for permanent residence. Several respondents in Denmark stated that rather than being encouraged to learn the language, they felt excluded by the Danish aliens' law.

Remarkably, in the United Kingdom (where there is no obligation to attend a course), nearly all immigrant respondents were sceptical about the likelihood that the 'Life in the UK' test would lead to integration. This high degree of scepticism is perhaps attributable to the fact that many newcomers in the United Kingdom are already proficient in the language of their country of immigration. This is different in the other countries studied.

Most of the other respondents (teachers, public officials, NGOs) were reluctant to claim that the language and knowledge-of-society requirements for permanent residence contributed to the integration process of those who have to 
meet them. Many of them thought that the required levels of language proficiency for permanent residence were not sufficient for successful participation in the labour market. These respondents did not think that applicants for permanent residence should be required to attain a higher level of language proficiency. However, they thought that it was unrealistic to expect an effect on the immigrants' integration in the labour market. On the other hand, in all countries with compulsory courses, there were many respondents who claimed that these had emancipatory effects for particular groups, e.g., young mothers and (other) immigrants who belong to rather closed communities, and who would not (be allowed to) attend a course if there was no obligation. Particularly in Germany and Austria, many respondents stressed that the psychological effects of the courses are probably more important than the language progress made by the immigrants who participate in the courses. However, particularly in Austria, some respondents also stressed that in the end, factors such as discrimination and the closed nature of mainstream society are more important for the integration process of immigrants than integration programmes and examinations.

\subsection{Effects on Permanent Residence and Security of Residence}

In Denmark, both the number of applications and the proportion of granted applications for permanent residence have declined sharply since 2006. The drop in the number of applications can be attributed to the seven-year residence requirement which was introduced in 2002, but the drop in the proportion of granted applications is most likely to have been caused by the requirement to pass a language test, which was also introduced in 2002, and sharpened up in 2007. Refugees have been affected most severely. Before 2006, less than 10 per cent of refugees' applications for a permanent permit were refused; in 2008 and 2009, the refusal rate was more than 50 per cent.

In the Netherlands, passing an examination has been a requirement for permanent residence only since January 2010. The Dutch statistics for the first six months of 2010 do show a decline in the number of applications in comparison to the previous year. This decline is probably partly attributable to the integration requirement. However, the fee for these applications was also raised. ${ }^{19}$ Moreover, the drop in the number of applications for permanent residence could also be due to more immigrants applying for naturalisation right away, without first applying for a permanent resident permit, as the integration examination also gives access to naturalisation.

In Latvia, the requirement to pass a language test has not led to a decline in the number of permanent permits granted. Likewise, in the United Kingdom, the requirement to demonstrate sufficient language and 'Life in the UK' knowledge has not led to a decline in the number of grants of indefinite leave to remain. 19) Ministerie van Justitie (2010), Rapportage Vreemdelingenketen. Periode januari-juni 2010, Ministerie
van Justitie, Den Haag, p. 31. 
However, it cannot be concluded from this that the requirement has not had deterrent effects, because the pool of potential applicants for indefinite leave has increased in the past decade. The interviews in the United Kingdom confirmed that in a number of cases migrants were not able to apply for indefinite leave to remain because they had not (yet) passed the 'Life in the UK' test.

In Austria and Germany, it was too early to establish an effect on permanent residence: the first cohorts of immigrants that have to comply with the language and knowledge requirements did not yet fulfil the five-year residence requirement in both countries. Some respondents thought that the income requirements in these countries constituted a bigger hurdle. Immigrants with low educational levels would have difficulties fulfilling both requirements at the same time. In both countries, an immigrant's failure to comply with the language and knowledge requirement may also have consequences for the renewal of his/her temporary residence permit. It can be assumed, given the high proportion of immigrants who had not yet complied with the requirement at the time of our research, that legal disputes will have to clarify whether and when this penalty can be imposed on family migrants in the coming years. Immigrant organisations in both countries reported a growing sense of unease in immigrant communities because of the imminent denial of the renewal of temporary or the granting of permanent residence permits.

From these findings it can be concluded that, in most cases, the language and knowledge requirements do help to limit access to permanent residence to 'well integrated' immigrants.

The consequences of not obtaining a national permanent status or the EU long-term resident status depend on the rights that are attached to these statutes. Both statuses offer their holders greater security of residence than a temporary permit. In the Member States where the permanent residence permit offers the highest security, the permit can be lost on three grounds only: fraud, long absence from the country, or long prison sentences. Holders of a permanent resident permit in these Member States do not have to fear losing their residence rights in the event of, e.g., dependence on public assistance, offences against public order, or, if they were admitted to the country on humanitarian grounds, in the event of an improvement of the situation in their country of origin. Article 12(1) of the Long-Term Residents Directive solely allows Member States to expel the longterm resident if he/she constitutes an actual and sufficiently serious threat to public policy or public security. In this regard, long-term residents enjoy the same protection as EU citizens. ${ }^{20}$ Article 9 of the Directive allows Member States to

\footnotetext{
20) A similar wording is used in Article 27(2) of Directive 2004/38/EC; recital 2 of Directive 2003/109/ EC recalls the Tampere conclusions, in which the European Council stated that the rights of holders of a long-term residence permit should be as near as possible to those enjoyed by EU citizens; the EU Court of Justice has given the same meaning to the public order clauses in Decision 1/80 and the Association Agreement EEC/Tunisia as to the clause in the EU Free Movement Directive (C-340/97 of 10 February 2000 Nazli; C-97/05, 14 December 2006, Gattoussi).
} 
withdraw the EU long-term resident status if the holder constitutes a threat to public policy, and such threat is not a reason for expulsion within the meaning of Article 12. Otherwise the status can only be withdrawn if the long-term resident was absent from the territory of the Community for a period of twelve consecutive months (Article 9(1)(c)).

In many Member States, there are social rights attached to a permanent status, e.g., equal access to the labour market or the full range of social benefits, or the right to family reunification. Holders of the EU long-term resident status in principle enjoy equal treatment with nationals regarding access to the labour market, education, social and tax benefits, access to goods and services including housing. ${ }^{21}$ In addition to formal rights, a permanent resident status may also give its holder access to, e.g., a mortgage or an employment contract. In most countries, banks will not grant mortgages to migrants with temporary residence permits, and employers may be hesitant to offer them an employment contract.

It is hard to see how being excluded from these rights could foster the integration of the immigrants in question.

\section{Legal Constraints}

To what extent are Member States allowed to require a certain level of integration before they grant a permanent or autonomous residence right to migrants after a legal residence of five years or more? In this regard, there is a significant difference between the national permanent permit, the EU long-term residence permit and the autonomous residence permit granted on the basis of the Family Reunification Directive. ${ }^{22}$ Where the Member States have a large margin of appreciation regarding the national permanent residence permit, they are restricted by the text and purposes of the two Directives while implementing them. Furthermore, their implementation has to be in compliance with EU law, including the fundamental rights of the EU and the union principles of effectiveness and proportionality.

Regarding these three categories of statuses, the EEC-Turkey Association Agreement offers Turkish workers and their family members a special position.

\subsection{National Permanent Residence Permit}

The conditions for granting a national residence permit are defined on the national level and their application is not subject of European supervision on the implementation. Only if the status is denied on discriminatory grounds, a thirdcountry national could invoke instruments like the Twelfth Protocol of the European Convention on Human Rights or the UN Convention on the Elimina-

\footnotetext{
21) Article 11(1). The paragraphs 2, 3 and 4 allow Member States to restrict the equal treatment toward certain rights.

22) Denmark, the United Kingdom and Ireland are not bound by the two EU Directives.
} 
tion of all forms of Racial Discrimination. There could be reason for such an appeal, given the different pass rates of the integration tests. They clearly show that the background of migrants influences their chances to pass the integration tests. This regards especially their nationality, age and education level.

\subsubsection{EEC-Turkey Association Agreement}

The EEC-Turkey Association Agreement limits the possibilities of Member States to impose integration requirements toward Turkish workers and their family members. The EU Court of Justice ruling in a case on residence permit fees charged by the Netherlands, held that the standstill clauses of the Additional Protocol and Decision 1/80 preclude the introduction into Dutch legislation of any new restriction on the admission of Turkish workers and their family members intending to exercise that freedom. ${ }^{23}$ This judgment implies that new restrictions on the access to a more secure residence status are also prohibited, if this status entails a better material position (for instance by the possibility to buy a house) and more access to the labour market. Several Dutch lower courts derived from this judgment that being obliged to attend courses, being threatened with a fine if the examination is not passed in time and being refused a permanent resident permit affects the circumstances in which the Turkish national works and resides in the Netherlands. ${ }^{24}$ Further they argued that the obligation to attend an integration programme and to pass a test cannot be imposed on Turkish workers and their family members, as the different treatment compared to EU citizens (who are exempted from the obligation) would constitute a discrimination on the basis of nationality and therefore a breach of Article 10(1) of Decision 1/80. The appeals of the municipalities against these decisions are still pending. The reasoning of the Dutch lower courts would also be applicable to Turkish workers and their family members applying for a permanent residence permit in another Member State. Although the Danish government decided because of the ECJ ruling to exempt Turkish nationals from the pre-entry integration test, it still requires them to pass the integration test for the obtainment of a permanent residence status.

\subsection{Directive on the Status of Long-Term Resident Nationals of Third Countries}

Third country nationals who apply for the EU long-term residence status enjoy more legal protection than applicants for a national permanent status, as they are able to invoke Directive 2003/109/EC concerning the status of third-country nationals who are long-term residents (hereinafter: the Directive) and the EU law. The Directive allows Member States to impose integration requirements at two

23) CJEU 29 April 2010, C-92/07 (Commission v. Netherlands).

24) Rechtbank Rotterdam 12 August 2010, LJN: BN3934 and LJN: BN3935; Rechtbank Roermond 15 October 2010, LJN: BO1206. See the case report of Narin Tezcan-Idriz in this issue. 
stages of residence: with the obtainment of a EU long-term status and with the admission of a holder of a EU long-term residence permit in a second Member State. Regarding the first situation, Article 5(2) offers the opportunity to require applicants to comply with integration conditions in accordance with national law'. This reference to the national law does not dismiss Member States from implementing the article in compliance with the principle of proportionality and with respect for the aim of the Directive. The Directive aims to promote integration and mobility within the EU for third country nationals, and to grant them comparable rights as EU citizens. ${ }^{25}$ According to the Preamble of the Directive, the rules for the examination of the application for a long-term resident status should not constitute a means of hindering the exercise of the right of residence. ${ }^{26}$ Nevertheless, Article 5(2) lacks explicit limits on the 'integration conditions' as well as a standstill provision. For these reasons, it has been criticized for being the 'Achilles heel' of the Directive. ${ }^{27}$

Half of the Member States bound by the Directive have made use of Article $5(2) .{ }^{28}$ The results of the INTEC project in these five Member States show that the obligation to fulfil integration conditions is likely to result in a decrease of the number of applications for a national permanent or the EU long-term resident status. Especially migrants with little formal education, older migrants, migrants with a refugee background and those from non-western or developing countries seem to be hindered by this obligation. As the integration requirement for the obtainment of a permanent or long-term status has been introduced only recently, it is not clear to what extent it leads to a delay of the obtainment or to a permanent exclusion of a secure and strong residence right. Nevertheless, the figures give sufficient ground for questioning whether the Directive allows this creation of an obstacle to the long-term status for certain groups. This way of application of the Directive could constitute indirect discrimination. ${ }^{29}$ Especially if the requirement constitutes a permanent obstacle, it could be incompatible with the

\footnotetext{
25) Recital 4, 18 and 2 of the Preamble of Directive 2003/109. C. Groenendijk and J. de Heer, (2006), 'Richtlijn langdurig ingezeten Derdelanders', Commentaar Europees Migratierecht, SDU, Den Haag. While recalling the Tampere conclusions of 1999, recital 2 defines approximation of the legal status of third-country nationals to that of Member States' nationals as an underlying purpose.

26) Recital 10 of the Preamble of Directive 2003/109.

27) Boelaert-Suominen, S. (2005), Non-EU nationals and Council Directive 2003/109/EC on the Status of Third Country Nationals who are Long-Term Residents. Five paces forward and possibly three paces back, Common Market Law Review 42, pp. 1011-1052.

28) Besides five Member States covered by the INTEC project (Austria, France, Germany, Latvia and the Netherlands), these are the Czech Republic, Estonia, Greece, Italy, Lithuania, Luxembourg, Malta, Portugal and Romania.

29) Recital 5 of the Preamble of Directive 2003/109 obliges Member States, in accordance with Article 21(1) of the EU Charter of the Fundamental Rights, to give effect to the provisions without discrimination on the basis of (inter alia) ethnic or social origin, genetic characteristics, language, membership of a national minority, fortune, disabilities or age. Article 21(2) of the Charter also prohibits discrimination on the basis of nationality.
} 
aim of the Directive to grant long-term resident status. As the duration of residence in the Member State is the main criterion for acquiring the status of longterm resident, this effect would also violate the proportionality principle. ${ }^{30}$ This is even more the case in the Member States where the level of the tests is high and the availability of prior language training inadequate. In all Member States, the integration requirement appears to be counterproductive to the integration aim of the Directive.

Article 15(3) allows second Member States to require long-term residents applying for a residence permit to comply with integration measures in accordance with national law, unless the third-country national has been required to comply with integration conditions in order to obtain the long-term resident status in the first Member State. The wording of the article implies limited possibilities for Member States in this situation. They may not require long-term residents to pass a language examination, but they can oblige them for instance to attend a language course. ${ }^{31}$ Four of the Member States studied, Austria, France, Germany and Latvia, nevertheless require long-term residents to pass an integration test.

\subsubsection{EEC/Turkey Association Agreement}

Turkish nationals who object to the integration condition attached to the obtainment of the EU long-term residence status, could invoke the standstill clauses of the Additional Protocol and Decision 1/80. Member States could argue that the integration condition does not constitute a new restriction, if they had introduced the requirement at the same time with the implementation of the Directive. But as the approximation of the (mobility) rights of Turkish workers and their family members to those of EU citizens is an important aim of the Association rules, imposing a requirement which is not applied to Union citizens while exercising their right to freedom of movement does not contribute to the aim of the Agreement.

\subsection{Directive on the Right to Family Reunification}

In all the Member States studied, family members are the largest target group of the integration requirements. Besides the EU long-term residents status, EU law entitles this group of third country nationals to a stronger residence right. According to Article 15(1) of the Family Reunification Directive, family members who have been admitted for reasons of family reunification have the right to an

\footnotetext{
30) Recital 6 of the Preamble of Directive 2003/109 explicitly states that duration of the residence is the main criterion.

31) During the negotiations, the Member States explicitly made this distinction between the wording of Article 5(2) (conditions) and Article 15(3) (measures), Council Document 7393/1/03 of 14 March 2003, p. 5. See also Groenendijk and De Heer 2006, supra fn. 25.
} 
autonomous residence permit after five years of residence in the Member State. Its Preamble mentions the aim of this right: 'The integration of family members should be promoted. For that purpose, they should be granted a status independent of that of the sponsor (...)'.32 In the Explanatory Memorandum of the proposal for the Directive, the Commission emphasised the need to enable family members to cease depending on the applicant's residence permit and to enjoy certainty as to their own legal position. ${ }^{33}$ The granting of an independent status after a certain period of residence also aimed to avoid the family becoming a prison..$^{34}$

Article 15(4) provides that the conditions relating to the granting and duration of the autonomous residence permit are established by national law. In its October 2008 report on the application of the Family Reunification Directive, the Commission made clear that this mandatory provision is to ensure the granting of the autonomous residence permit. The Commission observed that seven Member States violated this obligation by giving the authorities an inadmissible amount of discretion. ${ }^{35}$ This observation implies that the possibility to make conditions prohibits to create extra barriers to this independent residence right. In the Chakroun case, the EU Court of Justice argued in the same way regarding the possibility for Member States to require a certain level of income: 'Since authorisation of family reunification is the general rule, the faculty provided for in Article 7(1)(c) of the Directive must be interpreted strictly. Furthermore, the margin of manoeuvre which the Member States are recognised as having must not be used by them in a manner which would undermine the objective of the Directive, which is to promote family reunification, and the effectiveness thereof. ${ }^{36}$ Hence, the national discretion to make conditions for the obtainment of an independent residence right is limited by its purpose, which is the promotion of integration, legal certainty and independence of admitted family members.

Article 7(2) allows Member States to require family members to comply with integration measures. The second sentence of Article 7(2) implies that this provision is also applicable after family reunification has been granted. Whereas Germany only applies the integration condition for the obtainment of a permanent resident status and not for the obtainment of an autonomous resident status, the Netherlands and Austria apply the integration requirements in both situations. If Member States deliberately made a distinction between the wording 'measures' and 'conditions', it is important to define the exact meaning of the

\footnotetext{
32) Recital 15 of the Preamble of Directive 2003/86.

33) COM (1999) 638, p. 19.

34) Explanation by the Commission during the Council negotiations, 11524/00, 4 January 2001, p. 21.

35) COM (2008) 610 final of 8 October 2008, p. 13. These seven Member States are Bulgaria, Finland, Hungary, Italy, Romania, Poland, Slovenia. Estonia did not lay down any national rules at all.

36) C-578/08 (Chakroun v. Minister van Buitenlandse Zaken), paragraph 43, http:/www.curia.europa.eu.
} 
word 'measures'. ${ }^{37}$ May Member States require family members to pass a test or only to attend an integration course? The answer applies to both family reunification and the obtainment of an independent residence right. The Commission has not answered this question explicitly, but takes the view that the admissibility of an integration measure depends on whether it serves the purpose of facilitating the integration of family members and whether it respects the principle of proportionality.

One can doubt whether the obligation to pass an integration test effectively serves the integration of family members. In a worst-case scenario, it can even prove to be counterproductive, because a sponsor can keep his wife successfully dependent from his own residence permit by hampering her attempts to learn the language. It could be argued that, rather than an integration requirement, the granting of an independent residence right itself facilitates integration. According to the Directive, the five years of residence is sufficient justification for this right to legal certainty. If in addition a certain level of knowledge can be demanded, the most vulnerable migrants (elderly and low educated and migrants with a refugee background) are being kept in a weaker and dependent position, which might offer them less possibilities to participate and integrate. Given this effect, the integration condition is not in compliance with the obligation to implement the Directive without discrimination. ${ }^{38}$ Apart from the principle of effectiveness, the proportionality principle is also at stake. After all, the consequence of remaining in a dependent situation is serious. Less rigorous means to promote the integration or family members are thinkable, like offering integration courses or obliging them to attend them. Finally, according to Article 17 Member States have to take due account of individual circumstances while deciding on granting or renewing a residence permit. As the duration of the residence is mentioned as one of these circumstances, this provision creates an additional argument to attach the most weight to the five years residence as a criterion for granting an independent residence right.

\footnotetext{
37) Groenendijk derived from the negotiations on the Family Reunification Directive that the majority of the Member States opposed the insertion of the term 'conditions'. According to Groenendijk, these Member States apparently held that the term 'conditions' would be broader, making integration a condition for admission of the family member. See Groenendijk 2011, supra fn. 2, p. 6. Groenendijk explained the differences between the wording in Groenendijk, C. (2006). Family reunification as a right under Community Law, European Journal of Migration and Law 8, pp. 215-230. Carrera described the discussion in the Council about this wording in Carrera 2009, supra fn. 13, pp. 175-182 and 193-196 (during the negotiations on Directive 2003/109/EC) and pp. 166-171 (during the negotiations on Directive 2003/86/EC).

38) Recital 5 of the Preamble of Directive 2003/86 prohibits discrimination on the basis of (inter alia) ethnic or social origin, genetic characteristics, language, fortune, membership of a national minority, disabilities or age. Just like recital 5 of Directive 2003/109/EC, the wording is similar to Article 21(1) of the EU Charter on Fundamental Rights. Article 21(2) of the Charter also prohibits discrimination on the basis of nationality.
} 


\section{Conclusion}

While the stated aim of the language and knowledge-of-society requirements in all the countries studied is the same, namely to promote the integration of the target groups, there are important differences in approach. Particularly the extent to which the responsibility for acquiring the required knowledge is shifted toward the immigrant varies a lot. There are also important differences in the content and level of the knowledge required. As it is difficult to see why some countries should have higher requirements than others for the same need, these differences throw doubt on the argument that immigrants need the knowledge they are required to demonstrate in order to successfully integrate..$^{39}$ Moreover, there is a tendency to raise the required level or to sharpen the sanctions for non-compliance once the requirements have been introduced - often without the effectiveness of the previous requirements and sanctions yet having been evaluated. This strengthens the impression that the latent aim of the requirements is to limit access to permanent residence to 'well integrated' immigrants.

As has been observed by other authors, integration programmes, contracts and particularly standardised tests are attractive instruments for policy-makers because they enable a better control of the process of integration. They help to make the integration process 'administrable' - or at least help to create the impression that it is a manageable process. ${ }^{40}$ However, the use of standardised tests as policy instruments, to control access to permanent residence, also has its drawbacks. It more or less precludes the possibility of tailoring language and integration programmes to the needs of individual immigrants or different groups of immigrants. As it implies in most cases that the required level of language proficiency is set at, e.g., $\mathrm{A} 2$ or $\mathrm{B} 1$ for all immigrants seeking permanent residence, there are less possibilities to encourage and enable immigrants to acquire the level that best fits their capacities and needs than with a facilitating approach. ${ }^{41}$ This was confirmed in the interviews for the INTEC study. The required level of language proficiency was perceived by many respondents in most countries as being too low to improve the candidates' labour market position, but too high to include all immigrants who are willing to integrate.

\footnotetext{
39) Cf. McNamara, T. and Shohamy, E. (2008). Language tests and human rights. International Journal of Applied Linguistics 18, pp. 89-95; Van Avermaet, P. (2009). Fortress Europe? Language policy regimes for immigration and citizenship, in: Discourses on Language and Integration: Critical Perspectives on Language Testing Regimes in Europe. G. Hogan-Brun et al. (Eds.), pp. 15-43, Benjamins, Amsterdam.

40) Cf. Michalowski, I. (2004). Integration programmes for newcomers - A Dutch model for Europe?, IMISBeiträge 24, pp. 163-176.

41) Cf. Kuijper, H. (2008). Language tests for social cohesion and citizenship. Issues of quality assurance. Paper presented at the Intergovernmental Seminar 'The Linguistic Integration of Adult Migrants', June 2008, Strasbourg, Council of Europe.
} 
It is too early to assess the effects of the language and knowledge-of-society requirements on the integration process of the target groups. However, based on the interview results it can be doubted that making access to permanent residence conditional on the passing of a language or knowledge test will yield better results than an approach in which newcomers are encouraged and expected to attend language courses without this sanction. It is easier to assess the effects of the use of tests to control access to permanent residence on the security of residence of migrants admitted for non-temporary stay. In Denmark, there has been a sharp decline in the number of applications for and the number of permanent residence permits granted. A similar decline can be expected to occur in Austria, the Netherlands and Germany in the coming years. Moreover, some groups are or will be affected more severely than others. Data on pass rates for different nationalities as well as the results from the interviews indicate that immigrants from developing countries, immigrants with refugee and humanitarian statuses, older immigrants and immigrants with less formal education fare less well in the tests.

Generally, immigrants who fail the tests will not leave the Member State. They will continue to reside in the country with a temporary residence permit. It is hard to see how being excluded from a permanent status and the rights attached to it could foster the integration of the immigrants in question. Therefore, where a considerable proportion of the target group has difficulties fulfilling the language or knowledge-of-society requirements, the integration process is likely to be impeded rather than aided.

Given these effects, the use of tests to control access to permanent residence outdistances the position of third-country nationals from those of EU citizens, to whom integration requirements are not applicable. Whereas the European Council announced in 1999 that it intended to make the rights of third-country nationals comparable to those of EU citizens, in order to promote their integration, the national policies have turned in the opposite direction. ${ }^{42}$ Besides thirdcountry nationals, the own nationals of the Member States are affected as well. With the strengthened conditions for a stronger legal status for their spouses, the gap between their position and that of EU citizens to whom the free movement rules apply has become larger. This phenomenon of 'reverse discrimination' could affect the support for the European Union. It is yet to see to what extent the latest ruling of the Court of Justice regarding the consequences of citizenship of the European Union will affect the legitimacy of this different treatment. ${ }^{43}$

\footnotetext{
42) Conclusion no. 18. 'The European Union must ensure fair treatment of third country nationals who reside legally on the territory of its Member States. A more vigorous integration policy should aim at granting them rights and obligations comparable to those of EU citizens. It should also enhance nondiscrimination in economic, social and cultural life and develop measures against racism and xenophobia', Presidency Conclusions, Tampere European Council 15 and 16 October 1999, SN 200/1/99.

43) CJEU, 8 March 2011, C-34/-09 Zambrano v. Office National de l'emploi.
} 
The side effects of the use of tests to control access to (permanent) residence rights should be closely monitored. The European Union has a long tradition in integration policy based on a facilitating approach. Hopefully, the Commission will hold on to this tradition in its forthcoming Communication on an EU agenda for integration of third country nationals. ${ }^{44}$

44) The Commission announced this Communication in its Communication on the Commission Work Programme 2011, COM (2010) 623 final, Vol. II, 27 October 2010, p. 13, nr. 39. 